\title{
TEMPORAL VARIATIONS AND SOURCES OF N-ALKANOLS AND STEROLS IN SEDIMENTS CORE FROM ADMIRALTY BAY, ANTARCTIC PENINSULA
}

http://dx.doi.org/10.4322/apa.2014.074

\author{
Edna Wisnieski ${ }^{1{ }^{* *}}$, Márcia C. Bícego ${ }^{2}$, Rosalinda C. Montone ${ }^{2} \&$ César C. Martins ${ }^{1, \star \star}$
}

${ }^{1}$ Centro de Estudos do Mar, Universidade Federal do Paraná - UFPR, CP 61, CEP 83255-976, Pontal do Paraná, PR, Brazil 2Instituto Oceanográfico, Universidade de São Paulo - USP, Praça do Oceanográfico, 191, CEP 05508-120, São Paulo, SP, Brazil

e-mail: *ednawisnieski@gmail.com; **ccmart@ufpr.br

\begin{abstract}
Sterols, $n$-alkanols and phytol were analyzed in three sediment cores collected in different regions of Admiralty Bay (Barrel Point, Refúgio II and Ferraz). The concentrations of total sterols ranged from 0.91 to $13.99 \mu \mathrm{g} . \mathrm{g}^{-1}$, total n-alkanol from 0.20 to $2.14 \mu \mathrm{g} \cdot \mathrm{g}^{-1}$ and phytol from 0.13 to $2.38 \mu \mathrm{g} \cdot \mathrm{g}^{-1}$. Cholesterol was the most abundant sterol in the three cores, while the short-chain n-alkanols were the predominant n-alkanols. Phytol showed relatively low concentrations in all cores. These results indicate marine sources as responsible for the more dominant input of sedimentary organic matter with lower contributions from terrestrial sources. The vertical distribution of the organic markers analyzed was similar, with higher concentrations found at the top layers of all cores and the lower concentrations in the deepest layers, with some variations occurring along the profile. These changes may be the result of natural events and temperature oscillation over the last century which may have altered the dynamics of the supply of organic matter of the sediments of Admiralty Bay.
\end{abstract}

Keywords: organic matter, sterols, n-alkanols, Antarctic Peninsula

\section{Introduction}

Sterols and n-alkanols are organic markers present in the polar fraction of lipid extracts in marine sediments, being directly associated with primary production (Hudson et al., 2001). They are also essential to marine organisms, acting as key components of cell membranes and to the regulation of specific metabolic processes (Laureillard et al., 1997). These markers are used to distinguish terrestrial and marine sources of sedimentary organic matter through, generally, the number of carbon atoms present in the aliphatic chain, and identify organisms that act as sources of these compounds (Volkman, 1986; Faux et al., 2011).

The distribution of these compounds in sediment cores may be useful for the understanding of the temporal and local environmental changes based on natural and anthropogenic events in the recent past. The aim of this work was to identify variations in the input and the sources of sedimentary organic matter deposited in sediments from Admiralty Bay, through the determination of organic markers, such as sterols and n-alkanols.

\section{Materials and Methods}

\section{Study area}

The study area was defined as Admiralty Bay $\left(62^{\circ} 02^{\prime} \mathrm{S}\right.$ and $58^{\circ} 21^{\prime} \mathrm{W}$ ), the largest fjord in the South Shetland Islands, located on King George Island (Figure 1), with total area of $120 \mathrm{~km}^{2}$. It is formed by a $>500 \mathrm{~m}$ deep main channel, that divides the bay in three main inlets (Martel, Mackelar and Ezcurra), and in each there is a research station. The presence of high diversity of marine organisms, plants and animals, such as, fungi, mosses, birds and mammals, represents the sources of different classes of biomarkers. 


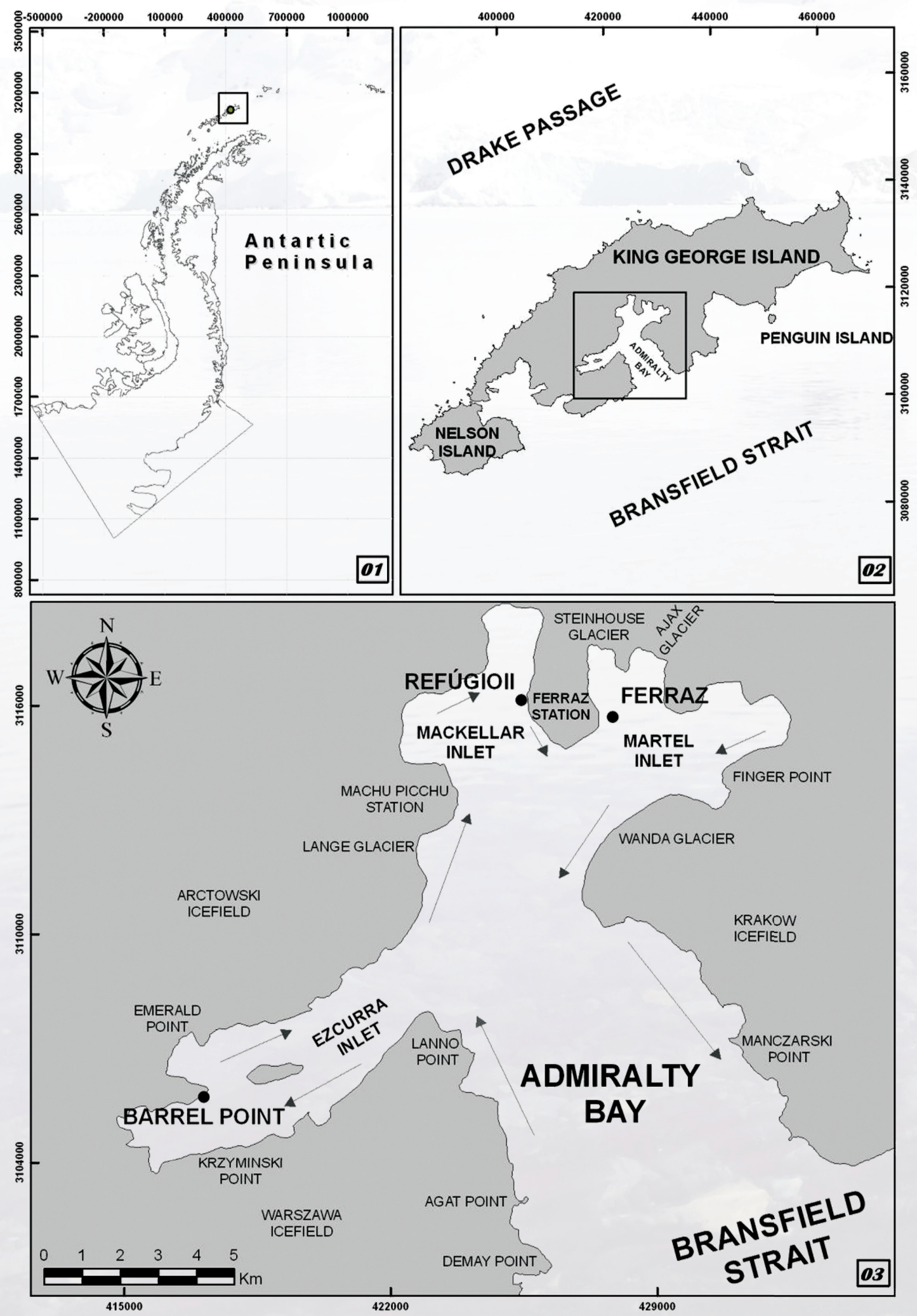

Figure 1. Map of the study region with three sampling stations at Admiralty Bay (03). The arrows indicate the current circulation direction within the bay (Rakusa-Suszczewski, 1980) 


\section{Sampling}

The sampling was carried out during the austral summer of 2006/2007 and 2009/2010, in three inlets around Admiralty Bay (Ferraz - FER, Barrel Point - BAR and Refúgio II - REF, Figure 1). The cores were obtained from a box core sampler, and sub-sampled into sections of $1 \mathrm{~cm}$ (except REF, where sections were $2 \mathrm{~cm}$ ).

\section{Analytical procedure}

The analytical method used to analyze the sterols and $\mathrm{n}$-alkanols in sediments was adapted from UNEP (1992) with modification. Around $20 \mathrm{~g}$ of sediment were extracted using a Soxhlet system during $8 \mathrm{~h}$ with $80 \mathrm{~mL}$ of $\mathrm{n}$-hexane: dichloromethane (DCM) (1:1) (both J.T. Baker), and with $100 \mu \mathrm{L}$ of a solution containing surrogates eicosene, hexadecene (50 ng. $\left.\mu \mathrm{L}^{-1}\right)$ and $5 a$-androstanol $\left(20 \mathrm{ng} \cdot \mu \mathrm{L}^{-1}\right)$. This extract was reduced to c. $2 \mathrm{~mL}$ by rotoevaporation and submitted to a clean up in column chromatography using $3.2 \mathrm{~g}$ of silica (silica gel 60, 0.063-0.200 mm, Merck) and $1.8 \mathrm{~g}$ of alumina (aluminum oxide 90 active, 0.063$0.200 \mathrm{~mm}$, Merck) (5\% deactivated). The samples were eluted with $10 \mathrm{~mL}$ of $\mathrm{n}$-hexane to fraction 1 (aliphatic hydrocarbons - not analyzed), $15 \mathrm{~mL}$ of $\mathrm{n}$-hexane/DCM
$30 \%$ to fraction 2 (PAHs +alkenones - not analyzed) and $5 \mathrm{~mL}$ of ethanol/DCM 1:9, following $20 \mathrm{~mL}$ of ethanol to fraction 3 (sterols and n-alkanols). The fraction 3 was evaporated to dryness and derivatized to form trimethylsilyl ethers using BSTFA (bis(trimethylsilyl)trifluoroacetamide) with $1 \%$ TMCS (trimethylchlorosilane) during 90 minutes at $65{ }^{\circ} \mathrm{C}$. The mixture of TMS-sterols and n-alkanols derivatives was determined by the injection of $2 \mu \mathrm{L}$ into a gas chromatograph equipped with a flame ionization detector (GC-FID).

\section{Results}

Seventeen sterols were identified, with total sterols concentration ranging from 0.91 to $2.17 \mu \mathrm{g} \cdot \mathrm{g}^{-1}$ (BAR), from 1.63 to $8.59 \mu \mathrm{g} \cdot \mathrm{g}^{-1}$ (REF) and from 2.64 to $13.99 \mu \mathrm{g} \cdot \mathrm{g}^{-1}$ (FER). The distribution of total sterols concentration according to the depth for three cores can be visualized in Figure 2.

Total sterols in BAR showed higher concentration between 7 and $11 \mathrm{~cm}$, with lower concentrations in deeper layers. In REF, higher concentrations were found from $7 \mathrm{~cm}$ toward the surface while FER showed some variations over time, with lower concentrations observed between 7 and $16 \mathrm{~cm}$ (Figure 2).
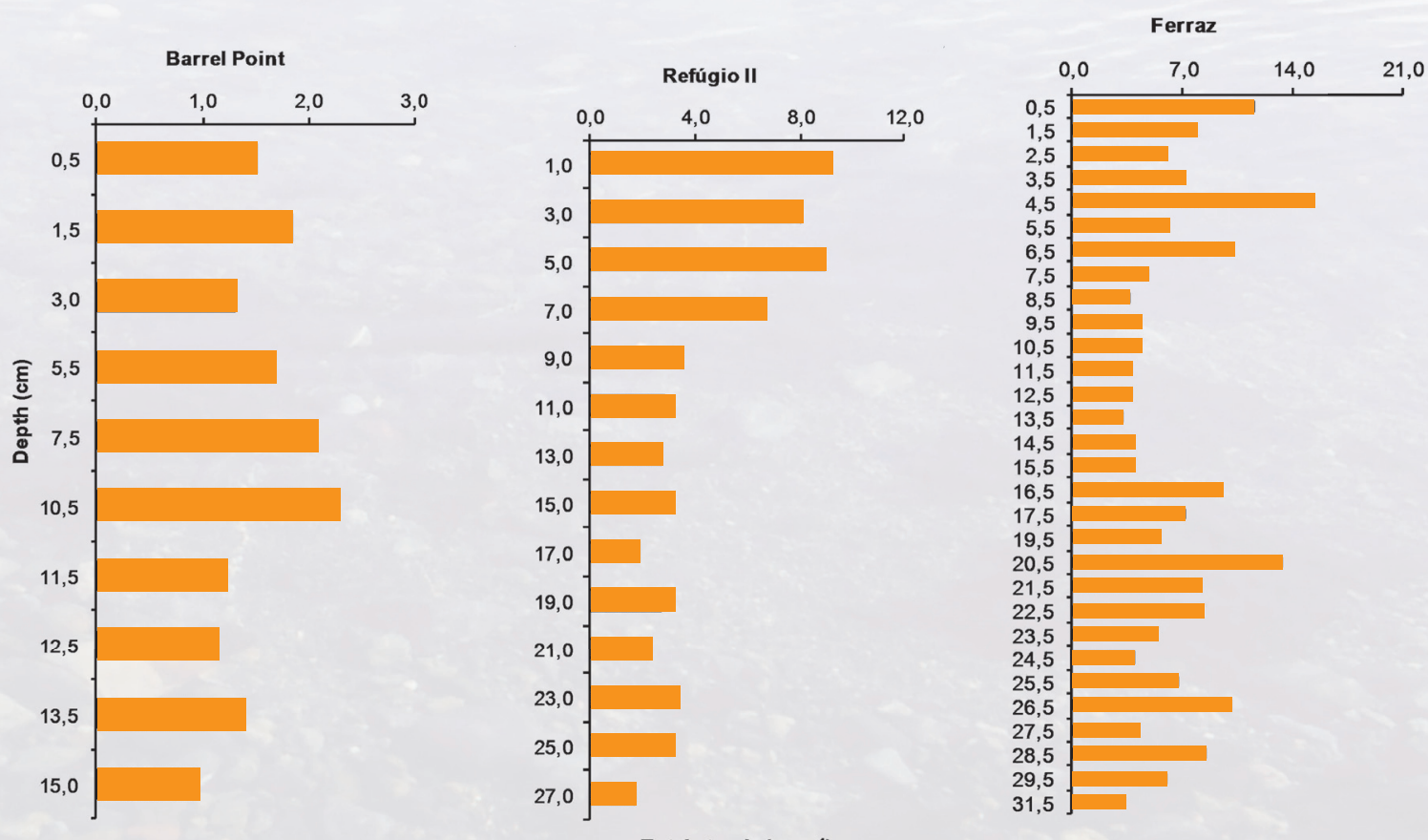

Figure 2. Vertical profile of total sterols (in $\mu \mathrm{g} \cdot \mathrm{g}^{-1}$ ) in sediment cores from Admiralty Bay, Antarctic Peninsula.

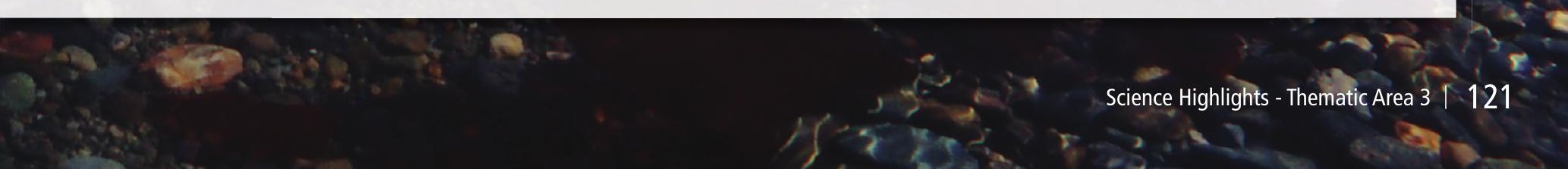


Fourteen n-alkanols were identified, with total n-alkanols concentration varies from 0.20 to $0.58 \mu \mathrm{g} . \mathrm{g}^{-1}$ (BAR), 0.33 to $2.14 \mu \mathrm{g} \cdot \mathrm{g}^{-1}$ (REF) and 0.22 to $1.97 \mu \mathrm{g} \cdot \mathrm{g}^{-1}$ (FER). The distribution of total $\mathrm{n}$-alkanols concentration in different layers for three cores is shown in Figure 3.

Total n-alkanols en BAR was similar to the total sterols, with highest concentrations between 7 and $11 \mathrm{~cm}$. In REF, the highest values of concentrations occurred between 7 and $9 \mathrm{~cm}$, while FER presented three concentrations peak at $16.5,6.5$ and $0.5 \mathrm{~cm}$.

Phytol, an isoprenoid alcohol derived from chlorophyll- $a$ degradation (Volkman et al., 2008), was found in all cores analyzed. The distribution of phytol concentration in different layers for three cores is shown in Figure 4.

Phytol concentration varied from 0.17 to $0.26 \mu \mathrm{g} \cdot \mathrm{g}^{-1}$ (BAR), 0.13 to $2.39 \mu \mathrm{g} \cdot \mathrm{g}^{-1}$ (REF) and 0.24 to $1.26 \mu \mathrm{g} \cdot \mathrm{g}^{-1}$ (FER). Relative low concentrations and close to the detection limit were presented in the BAR, while REF and FER showed highest concentrations in top core sections, represented as the recent sediments. In the others sections, a regular distribution with no significant variations was observed.

\section{Discussion}

The variation observed along vertical profiles, for both sterols as n-alkanols, may reflect variations in the input of organic matter in the environment, besides the section with higher concentration indicating higher contributions of sedimentary material, while sections with decreased values indicate a low input or organic matter reduction on sediments (Meyers, 1997). These variations may occur due to environmental changes, which have an influence on the organic matter processes related with the input, burial and preservation and/or degradation (Faux et al., 2011), or as the result of natural variability. The decreased concentrations with core depth were not constant and may also be a result of diagenesis (Burns \& Brinkman, 2011).

Cholesterol was the most abundant sterol. Several organisms that inhabit the region are potential sources of cholesterol, including seal, whales and phyto and zooplankton (Volkman, 2005). The detectable concentration of 17 different sterols analyzed is an evidence of the large sources diversity of organic matter contributing to the sediment composition in Admiralty Bay. The presence of
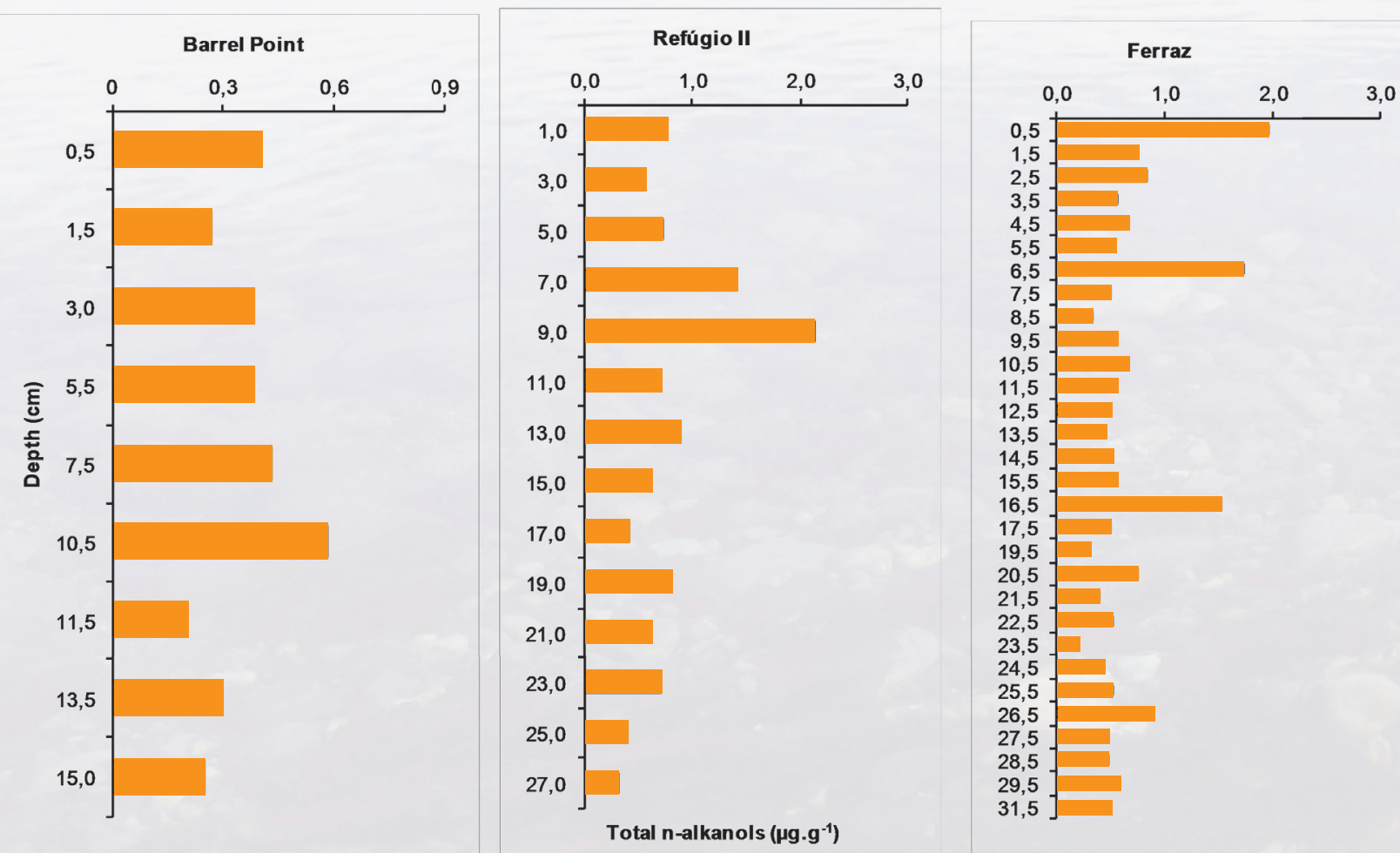

Figure 3. Vertical profile of total n-alkanols (in $\mu \mathrm{g} \cdot \mathrm{g}^{-1}$ ) in sediment cores from Admiralty Bay, Antarctic Peninsula. 

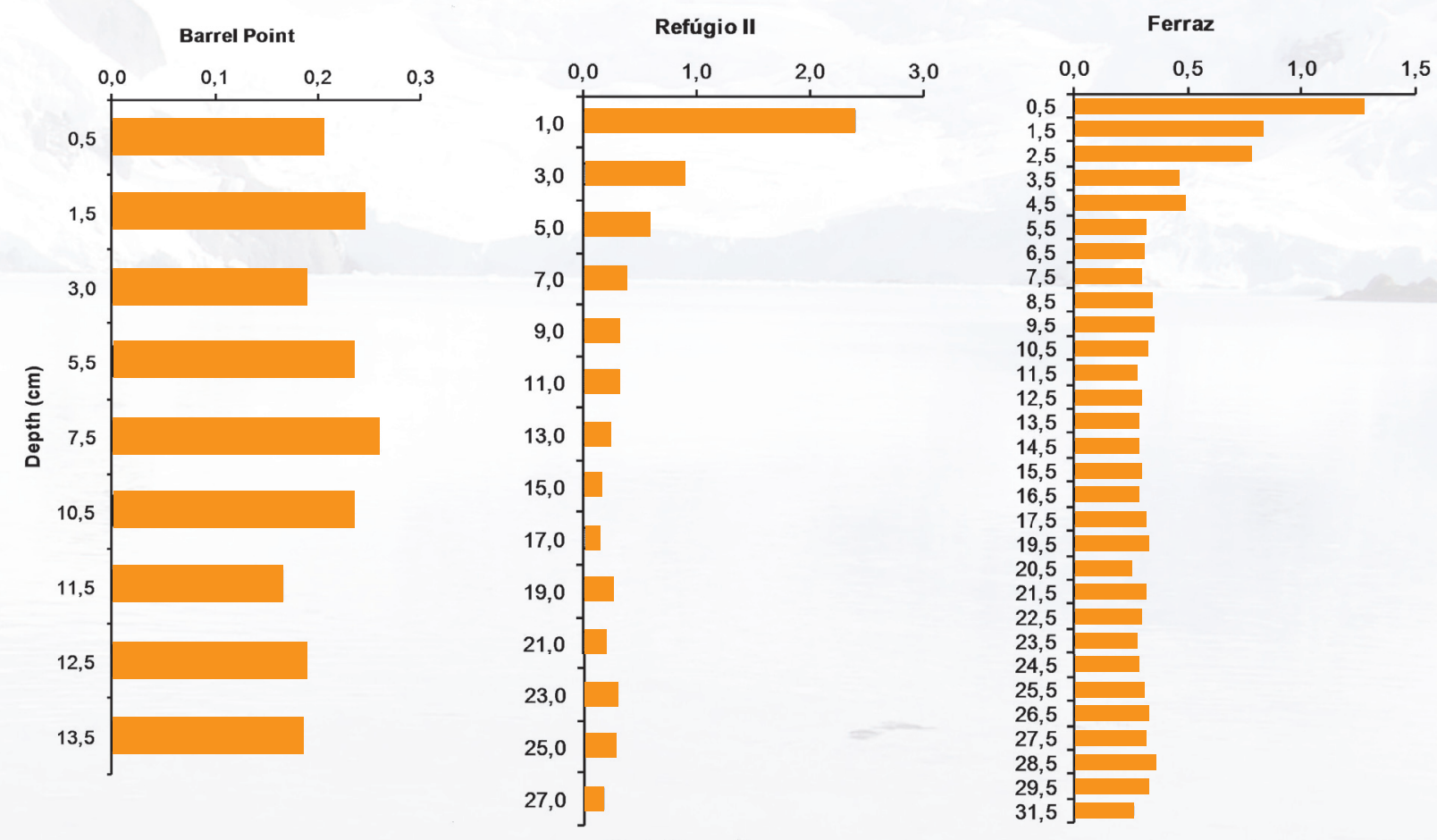

\section{Phytol ( $\left.\mu g \cdot g^{-1}\right)$}

Figure 4. Vertical profile of total phytol (in $\mu \mathrm{g} \cdot \mathrm{g}^{-1}$ ) over the cores in Admiralty Bay, Antarctic Peninsula

saturated sterols in sediments indicates the occurrence of diagenic process due to the fact that they are not commonly found with significant abundance in organisms (Hassett \& Lee, 1977).

The predominance of short-chain $\mathrm{n}$-alkanols in all cores suggest the organic matter in this region is primarily associated with marine organisms, which include sources like, aquatic algae and bacteria (Xiong et al., 2010), zooplankton (Burns \& Brinkman, 2011) and hydrolysis of the wax esters of zooplankton which may increase the saturated and unsaturated $\mathrm{C}_{14}-\mathrm{C}_{22}$ alcohols (Volkman, 2006).

In Antarctic region, phytol contribution is related to vascular plants (D. Antarctica e C. quitensis), lichens, mosses and algae (Wang et al., 2007). However, the low concentrations observed in all cores in this study compared to marine sediments from temperate/tropical areas may be related with the absence of significant sources for this compound in the region. Another explanation is to low phytol concentration is related to the degradation compound in sediments, which includes aerobic and anaerobic biodegradation, photo degradation and sulphurization in sediment-water interface.

\section{Conclusions}

Based on the results, a multiplicity of sources of marine organic matter from sediments from Admiralty Bay could be verified, mainly associated with marine origin, with little contribution from terrestrial material. Despite of the transformation processes of organic matter, the compounds showed relative preservation, representing the variations and distribution of organic matter along the vertical profiles.

This study is a first insight about polar organic markers in sediment cores of Admiralty Bay and the results, after more deeper interpretation and including other proxies (e. hydrocarbons, elemental and isotopic analyses) may contribute to a better understanding of the processes related to organic matter contribution and the changes as a result of natural events and temperature oscillation over the last century.

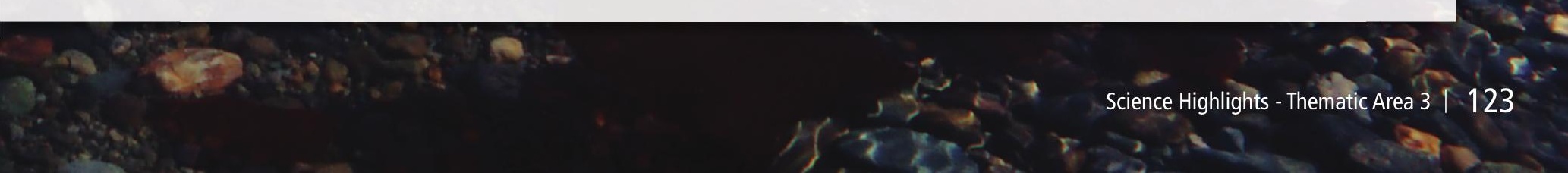




\section{Acknowledgements}

This work integrates the National Institute of Science and Technology Antarctic Environmental Research (INCTAPA) that receives scientific and financial support from the National Council for Research and Development (CNPq process: $n^{\circ}$ 574018/2008-5) and Carlos Chagas
Research Support Foundation of the State of Rio de Janeiro (FAPERJ nº E-16/170.023/2008). The authors also acknowledge the support of the Brazilian Ministries of Science, Technology and Innovation (MCTI), of Environment (MMA) and Inter-Ministry Commission for Sea Resources (CIRM).

\section{References}

Burns, K. \& Brinkman, D. (2011). Organic biomarkers to describe the major carbon inputs and cycling of organic matter in the central Great Barrier Reef region. Estuarine, Coastal and Shelf Science, 93: 132-141.

Faux, J.F.; Belicka, L.L. \& Harvey, H.R. (2011). Organic sources and carbon sequestration in Holocene shelf sediments from the western Arctic Ocean. Continental Shelf Research, 31: 1169-1179.

Hasset, J.P. \& Lee, G.F. (1977). Sterols in natural water and sediments. Water Research, 11: 983-989

Hudson, E.D.; Parrish, C.C. \& Helleur, R.J. (2001). Biogeochemistry of sterols in plankton, settling particles and recent sediments in a cold ocean ecosystem (Trinity Bay, Newfoundland). Marine Chemistry, 76: 253-270.

Laureillard, J.; Pinturier, L.; Fillaux J. \& Saliot, A. (1997). Organic geochemistry of marine sediments of the Subantarctic Indian Ocean sector: Lipid classes - sources and fate. Deep-Sea Research II, 44: 1085-1108.

Meyers, P.A. (1997). Organic geochemical proxies of paleoceanographic, paleolimnologic, and paleoclimatic processes. Organic Geochemistry, 27(5-6): 213-250.

Rakusa-Suszczewski, S. (1980). Environmental conditions and the functioning of Admiralty Bay (South Shetlands Islands) as part of near shore Antarctic ecosystem. Polish Polar Research, 1: 11-27.

United Nations Environment Programme - UNEP. (1992). Determination of petroleum hydrocarbons in sediments. United Nations Environment Programme Reference Methods for marine pollution studies, 20: 1-75.

Volkman, J.K. (1986). A review of sterol markers for marine and terrigenous organic matter. Organic Geochemistry, 9: 83-100.

Volkman, J.K. (2005). Sterols and other triterpenoids: source specefety and evolution of biosynthetic pathways. Organic Geochemistry, 36: 139-159.

Volkman, J.K. (2006). Lipid Markers for Marine Organic Matter. Handbook of Environmental Chemistry. part. 2, p. 27-70.

Volkman, J,K.; Revill, A.T.; Holdsworth, D.G. \& Fredericks, D. (2008). Organic matter sources in an enclosed coastal inlet assessed using lipid biomarkers and stable isotopes. Organic Geochemistry, 39: 689-710.

Wang, J.; Wang, Y.; Wang, X. \& Sun, L. (2007). Penguins and vegetations on Ardley Island, Antarctica: evolution in the past 2,400 years. Polar Biology, 30: 1475-1481.

Xiong, Y.; Wu, F.; Fang, J.; Wang, L.; Li, Y. \& Liao, H. (2010). Organic geochemical record of environmental changes in Lake Dianchi, China. Journal of Paleolimnology, 44: 217-231. 